\title{
Early herders of the Eastern Adriatic
}

\author{
Dimitrij Mlekuž \\ Department of Archaeology, University of Ljubljana, SI \\ dimitrij.mlekuz@uni-lj.si
}

\begin{abstract}
The paper discusses the evidence for the presence of sheep and goats on east Adriatic coast during the Mesolithic and Neolithic, and possible routes of transformation from hunter-gathering to pastoral societies.
\end{abstract}

IZVLEČEK - Članek kritično ovrednoti dokaze za prisotnost ovc in koz na vzhodnojadranski obali v mezolitiku in neolitiku in predstavi možne transformacije lovsko-nabiralniških skupnosti v pastirske.

KEY WORDS - Mesolithic; Neolithic; hunting-gathering; herding; East Adriatic

\section{INTRODUCTION}

Sheep and goat flocks were ubiquitous on the east Adriatic coast only a few decades ago. They formed the subsistence base and way of life for countless villages and families.

The image of herds grazing on the stony Mediterranean landscape seems somehow timeless, but was it always like that? I am going to discuss the process of transformation of Mesolithic and Neolithic societies on the east Adriatic coast, where sheep and goats were the medium and agents of this change. I argue that the transformation of these societies was structural and involved much more than just the adoption of sheep and goats.

\section{HUNTING-GATHERING AND HERDING}

The main difference between hunting (and gathering) and herding is social (cf. Bender 1987; Hayden 1990). It lies in the contradicting rationalities of sharing 1 and accumulation, based on the principles of collective and divided access to the means of subsistence (Ingold 1980.2-3). This observation has a series of corrollaries, which define pastoralist societies.

While in a hunting economy animals belong to no one and therefore everyone has a right to their meat, hunters derive a collective security in the face of fluctuating resources through regulations of sharing. In a pastoral economy, animals constitute property over which the owner has an exclusive right of disposal, thus pastoralist must insure themselves individually against future catastrophes of unknown magnitude by maximizing their reserves in the number of animals (Ingold 1980.89). Herding societies' production units are therefore fragmented, often equivalent to households (Sahlins 1972; Hesse 1984). Accumulation involves the appropriation of the natural increase, therefore production of meat, which entails the elimination of animals from reproduction, and is limited to the satisfaction of immediate domestic needs (i.e. underproduction; Sahlins 1972), which in consequence limits population growth.

\footnotetext{
1 As emphasised by Tim Ingold (1986), there are two forms of sharing, sharing out, as a form of distribution and sharing in, as a principle of collective access, which inheres in hunter-gatherer social relations and practices. This latter meaning of the word sharing is used throughout this paper.
} 


\section{AGENTS AND MEDIA OF CHANGE: SHEEP AND GOATS}

The domestic goat (Capra hircus) is often dismissed as the "poor man's cow" for its ability to thrive on meagre fodder and cope with harsh environments. Archaeological and genetic evidence clearly demonstrate that goats were, in the form of its wild progenitor - the bezoar (Capra aegagrus) - one of the first domesticated animals (MacHugh and Bradley 2001). Luikart et al. (2001) demonstrated that structure and distribution of mtDNA variation in domestic goats are qualitatively different from the patterns observed in other large Eurasian domesticated herbivores. Goats seem to have three and not two matrilineal roots, which raises the possibility of additional domestications. Moreover, the global distribution of goat mtDNA variation shows a remarkably low level of phylogeographic structure (particularly when compared with domestic cattle). This basically means that geographical location has little relevance to the mtDNA type a particular animal possesses. $\mathrm{Ba}$ sed on the antiquity of goat domestication and the presence of goats in almost every corner of Eurasia stretching deep into prehistory, we might expect that goats should display a high level of geographical structuring. Luikart et al. (2001) therefore suggest that goats have been a highly mobile species, which has expanded along human exchange networks.

The wild ancestors of modern domestic sheep still remain uncertain. There are three presumptive candidates (the urial, mouflon and argali; Ryder 1983).

As demonstrated by Hiendleder et al. (1998; 1998a), domestic sheep mtDNA haplotypes can be divided into two divergent lineages. One can be found only in European domestic sheep, while the other type is uncommon in Europe, but common elsewhere. The European mitochondrial lineage is similar to the mouflon type, while for the other lineage they found no similar connection to any of the three wild species. This strongly supports the hypothesis that modern domestic sheep and the European mouflon derive from a common ancestor and provides evidence of an additional wild ancestor, other than the urial and argali groups, which has yet to be identified, but may be sought among Anatolian mouflon.

\section{SPATIAL CONTEXT: DINARIDES}

The Dinarides mountain range extends along the Adriatic coast from the eastern Alps in the north to the Albania massifs in the south (Fig. 1). It rises abruptly from sea except for narrow coastal plains in Istria and between Zadar and Šibenik. With peaks as high as $2538 \mathrm{~m}$, it creates a climatic divide between the Mediterranean and continental climate immediately to the east. The Massif is broken only by rare river valleys, such as the Neretva, and is a serious barrier to communication; even today it is traversed at only a few passes. To the west, a series of long, narrow islands parallel the coast.

The whole area is characterised by limestone geology and is a landscape of classic karst topography. Although the region experiences extremely heavy rainfall, there is a general lack of surface water. The porous limestone quickly absorbs water via cracks and fissures, draining the surface. Subsurface water is conducted to vast, seasonally flooded depressions (poljes) in the Dinarides, or underwater springs along the Adriatic coast. Soils - except in depressions - are thin and leached (terra rosa), and as a result of millennia of overuse some parts of the landscape are virtually barren.

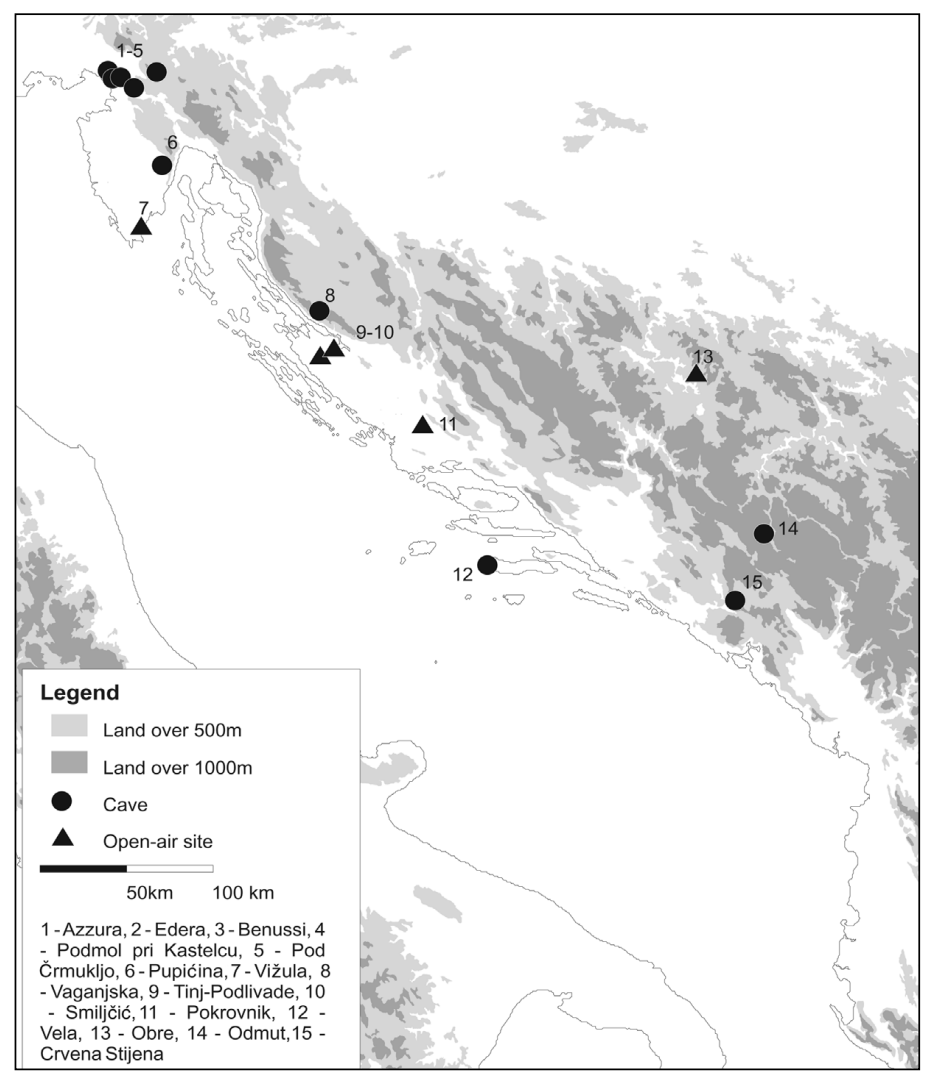

Fig. 1. The Dinarides and east Adriatic, with important sites mentioned in the text. 


\section{TRADITIONAL PRACTICES}

There is a long history of the practice of transhumant pastoralism in the Dinaric region. We have inscriptions from Roman times (Šašel 1979) which suggest that the practice can be dated deep in prehistory.

Ethnographic data from the Dinarides (Cvijic 1966; Vriščak 1989; Marković 1971) offer rich evidence of various traditional ways of keeping of sheep and goats by various semi-nomad, transhumant and semi-transhumant strategies, which were specific for each group involved and are very difficult to generalize (Fig. 2).

The most frequent pattern recorded is of "normal transhumance" where groups, living on the Adriatic coast take their flocks to the mountain pastures every summer, where they have established cabins (katuni). In a number of cases they have established more permanent settlements, where they live with their herds and families during the summer. This phenomenon of double villages is attested for Velebit.

Some groups move to the uplands and back down in a series of stages, with temporary stops at each stage. There are even cases of semi-nomadic herders spending the warmer part of the year wandering around with all of their possessions, and spending the colder part of the year in low-lying villages, often in very simple buildings.

Another pattern is of "inverse transhumance" - often associated with Vlachs where groups descend from the mountains in winter to pasture their sheep on the coastal pastures, returning to the mountain pastures in the spring.

There is also evidence of combined transhumance, typical of the herders of the Lika polje, but also documented elsewhere. The Lika herders moved their flocks into the mountains in spring and descended to the coast in the winter.

This rich range of flock movement strategies is no doubt a product of the very complex economic, demographic, political and environmental history of the region. A complex web of strategies was invented to adjust to population move- ments (especially Vlachs) connected with the expansion of Ottoman Empire, conflicts on the OttomanVenetian-Habsburg border, and the demands of Venetian coastal towns, Venice itself, and later, Austrian ports, physiocratic attempts to rationale agriculture, changing patterns of land ownership, raiding by hinterland brigands (hajduks), or the depletion of pastures... Complex pattern of transhumance strategies, observed in a historical and ethnographical records, is a result of an on-going process of interaction between people and landscape and a dynamic response to political, economical and environmental rhythms. Thus, ethnographically documented transhumant practices in the Dinarides should not be seen as fossil strategies remnants from the deep past, but as a dynamic response to changing conditions and practices always in a process of negotiation and becoming.

\section{THE USE AND ABUSE OF ETHNOGRAPHIC EVIDENCE}

The rich ethnographic evidence has lured many researchers to use it as a direct analogy to explain (early) Neolithic settlement patterns and patterns of material culture distribution.

Sterud (1978) used direct ethnographic evidence for long-distance transhumance from Adriatic coast on the one hand and the Sava Plain on the other to the mountain pastures in central Bosna in a very straight-

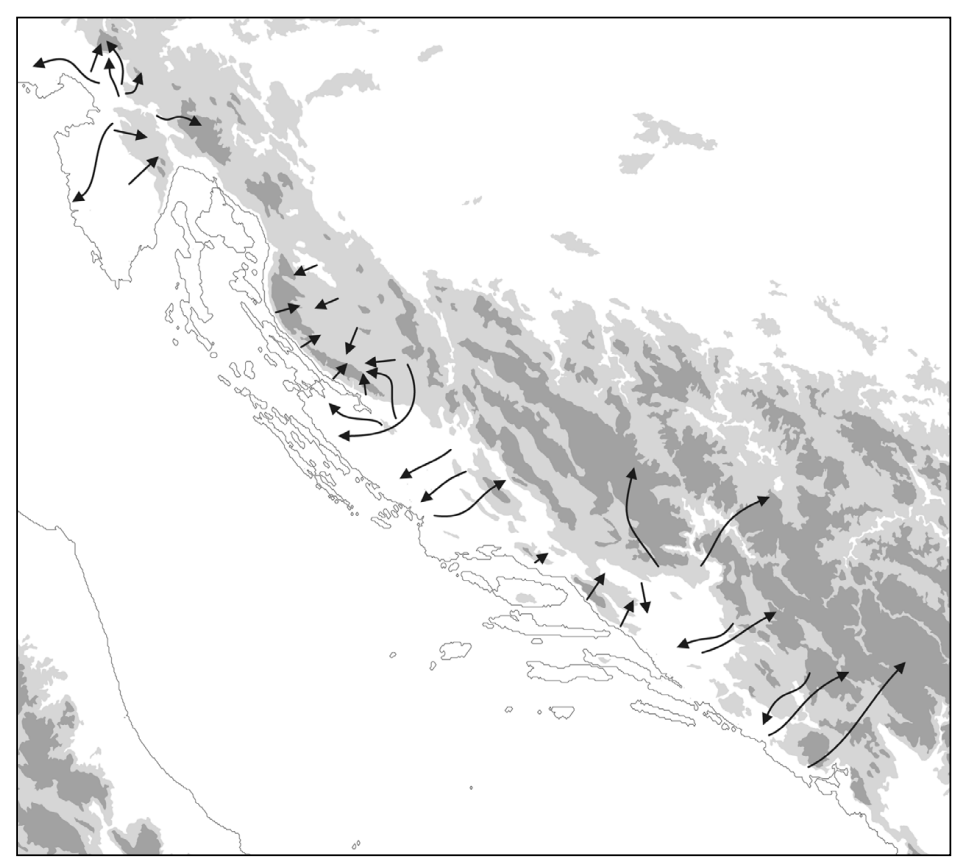

Fig. 2. Traditional transhumant routes in the Dinarides (compiled from Cvijić 1966; Vriščak 1989; Marković 1980). 
forward way to explain Mediterranean (Impresso) and continental (Starčevo) aspects of material culture found at the Obre I site. He sees long-range transhumance as a prime medium for cultural contacts and exchange in the early Neolithic.

Although refreshingly imaginative, his approach can be criticized on two grounds.

The main criticism can be directed to his use of ethnographic data. Traditional transhumance routes, which he uses to demonstrate long-range transhumance, are the result of extremely complex historical and economic factors, which evolved over millennia of herding (see above). It is very improbable that routes recorded at the beginning of the $20^{\text {th }}$ century are the same as those in the very early Neolithic. The ecological niche occupied by modern transhumant pastoralists simply did not exist in prehistory (Halstead 1987; Lewthwaite 1981; see below).

Questionable is also his idea of the very early establishment of long-range transhumance routes. Radiocarbon dates for the Obre I site are surprisingly early (sequence begins at ca. $6100 \mathrm{BC}$ ) 2 and are among earliest Neolithic dates in the Dinarides; it is, in fact, earlier than dates for open air sites on the Adriatic coast. One can hardly imagine the establishment of long-range transhumance routes from the coast to the high Karst mountains at very beginning of the Neolithic on the Adriatic coast.

Joannes Müller (1994) compared the early Neolithic settlement pattern in Ravni kotari, where open-air sites in the costal plain (Smiljčić, Tinj-Podlivade...) and cave sites in the Velebit mountain (Vaganjska pećina) are documented, with modern settlement patterns, with permanent villages in the lowlands and seasonal settlements (katuni) in the mountains.

Although the exploitation of the vertical gradient is possible, the long occupation history of Vaganjska cave - which extends deep in Palaeolithic - is in strong contrast with open air sites which were established after $6000 \mathrm{BC}$. Possible finds of capriovid bones in the Mesolithic layers of Vaganjska (Forenbaher and Vranjican 1985) possibly demonstrate an older and different presence of capriovid in Mesolithic societies (see below) than those documented in Neolithic lowland villages.

\section{"MESOLITHIC SHEEP”?}

There are several collections of capriovid bones found in Mesolithic contexts along the Adriatic coast, which opens up the possibility for the very early adoption of capriovids in hunter-gathering societies. However, these collections are not without problems.

I will present two possible chronologies for the introduction of the capriovids to the east Adriatic, long and short one, each based on different sets of evidence.

The long chronology of capriovid presence in the east Adriatic extends before $7000 \mathrm{BC}$ and is based on few and problematic data, whereas the short chronology starts at around $6000 \mathrm{BC}$ and is widely documented by large faunal collections (capriovid bones often predominate in the faunal record) in contexts often associated with pottery, whether Impresso or monochrome.

Collections of capriovids were found in west Mediterranean Mesolithic contexts, where in the ' 80 s and early ' 90 s there was an active discussion on the status of these finds (cf. Geddes 1983; 1985; Zilhão 1993; Binder 2000).

The local domestication of goats was suggested for Cova Fosca dated to ca. $6400 \mathrm{BC}$ (Olaria 1988). A large collection of sheep bones was identified in the Castelnoven layers at Châteauneuf, and the late Mesolithic acquisition of exotic domestic sheep through a long distance exchange mechanism was suggested for Abri Dourgne and Grotte Gazel, among others (Geddes 1983; 1985).

These finds have been lately largely discounted as being the result of various "taphonomic filters" (Zil$h \tilde{a} o$ 1993; 2001), the weather being intrusive from overlying Neolithic layers, the result of bad excavation practices, and/or analytical biases due to the mistaken misidentification of ibex as capriovid bones (Binder 2000.130-131).

Similar collections were found on the east Adriatic coast (Tab. 1). Layer 5 in Grotta Benussi (Pejca na Sedlu) in the Trieste Karst contained 5 capriovid bones in a late Sauvettarien context dated ca. 7400 BC. Subsequent layers (layer 4, dated to ca. 6400 BC and layer 3, dated to ca. $6000 \mathrm{BC}$ ) contained similar number of capriovid bones (Riedel 1975). Grotta

2 All data in the paper are in calendar years BC. 


\begin{tabular}{|lcccl|}
\hline Site & Layer & Date & $\begin{array}{c}\text { Capriovid } \\
\text { NISP }\end{array}$ & Reference \\
\hline Grotta Azzura & 4 & Mesolithic & 12 & $\begin{array}{l}\text { Wilkens 1992; } \\
\text { Cremonesi et al. 1984 }\end{array}$ \\
\hline Grotta Benussi & 5 & $8380 \pm 70($ R-1045) & 5 & Riedel 1975 \\
\hline Grotta Benussi & 4 & $7620 \pm 150($ R-1044) & 8 & Riedel 1975 \\
\hline Grotta Benussi & 3 & $7050 \pm 60($ R-1043) & 9 & Riedel 1975 \\
\hline Podmol pri Kastelcu & 13 & Mesolithic & 5 & Turk et al. 1993 \\
\hline Pod Črmukljo & & Mesolithic & 1 & Pohar 1986 \\
\hline Vaganjska Pećina & 1 & Mesolithic & $? ?$ & $\begin{array}{l}\text { Forenbaher and } \\
\text { Vranjican 1985 }\end{array}$ \\
\hline Crvena Stjena & IV & Mesolithic & $? ?$ & Malez 1975; Basler 1983 \\
\hline
\end{tabular}

Tab. 1. Evidence for the "long chronology" of capriovid presence on the east Adriatic coast.

Benussi is especially important because no Neolithic layers were found, thus intrusion seems less probable.

Similar finds of caprovids in a Mesolithic context were found in Podmol pri Kastelcu, where 5 sheep bones were found in layer 13, dated to the Mesolithic (Turk et al. 1993.71-73).

Wilkens (1992; Cremonesi et al. 1984) identified 8 sheep and 4 sheep or goat bones in Castelnovien layers at Grotta Azzura (Pečina na Leskovcu) in the Trieste Karst.

A rock shelter at Pod Črmukljo contained one sheep incisor (Pohar 1986) in a Mesolithic context.

A similar situation can be observed in Dalmatia, Herzegovina and Montenegro. Layer IV in Crvene stjene in Montenegro contained goat (Malez 1975) and sheep bones (Basler 1983) in a Castelovien layer IV underlying layer III with Impresso pottery.

Forenbacher and Vranjican (1985) mention the possible presence of capriovid bones in Mesolithic layers of Vaganjska pećina in Velebit Mountain.

Surprisingly, these collections were mostly ignored by archaeologist (except Budja 1993, which discusses them in the context of "transition to farming"; see also Velušček 1995; Budja 1996). Not fitting into rigid periodic schemes, they were usually dismissed as being intrusive from overlying Neolithic layers and attributed to taphonomic processes and bad excavation practices.

A discussion about the local domestication of wild sheep and goats by Castelnovien groups was raised by some zoo-archaeologists, but it never entered into archaeological discourse. Riedel (1975) discusses the probability of local domestication in the case of Grotta Benussi and Malez (1975) interprets finds from Crvene stijene as evidence for the existence of a wild goat ("Balkan goat") population in the Balkans in the early Holocene, which was husbanded by Mesolithic groups.

In my opinion, there is far too much evidence of the early presence of capriovids in Mesolithic contexts to be dismissed as being simply the result of various taphonomic filters (cf. Zilhao 1998, 2001; Velušček 1995; Wilkens 1992). However, this question will not be resolved until direct dates of bones become available.

If we accept that those collections are not the result of taphonomic agency, then how did they come to be in Mesolithic contexts?

The local domestication of sheep and goat by Mesolithic groups seems highly improbable in the light of new analyses of sheep and goat mtDNA (see above). If we accept the early presence of sheep and goats in the east Adriatic, they must have been somehow transported from their centre of domestication, somewhere in south-eastern Anatolia. What, then, were the actual mechanics of transporting capriovids to the east Adriatic coast?

"Commensal politics", negotiations of power through competitive feasting, may have started to become important during the Mesolithic in Europe. Exotic animals may have been important prestige items in competitive feast systems operating on the Adriatic coast (Miracle 2001), where seasonal aggregations may have been used as arenas for competition among power- and status-aspiring individuals. Social events such as competitive feasting were actively manipulated to undermine the principles of sharing and set in motion the process of the emergence of social inequality (Hayden 1995).

Miracle's (2001) interpretation of a midden in Pupićina Cave in Istria suggests increased social tensions, which were negotiated through commensal feast. Exotic items and food such as capriovids may have 
been actively used for display and consumption in a context of power negotiations between individuals and between groups.

The small sizes of bone collections suggest that sheep and goats were not herded, but were used only for display and feasts.

Alternatively, sheep and goats might also have been used as a risk buffer which allowed individuals to avoid obligations of sharing that were valid for hunted animals (Ingold 1980). In this way they probably played an important role in "relaxing" the ideology of sharing and offered a means for the introduction of an ideology of accumulation.

Another question is how they were actually brought several thousand kilometres from Near East.

There were a series of potentials that were opened up by the sea for individuals ( $c f$. Warren 1997). The sea was not a barrier. Travelling by water was not only a viable alternative to overland journeys, but offered individuals increased mobility by avoiding power relations defined by existing social structures of mating and exchange networks. Sea travel offered opportunities for establishing long-range contacts and thus enabled them to act as middlemen (or middle-women) for prestige items. Seascapes became landscapes of social opportunities through the establishment of long-range contacts and links for the exchange of partners, information, and prestige items.

Alternatively, the emergence of endogamous (closed) mating networks especially in a linear (coastal) environments would lead to local inequalities for groups located on the periphery of a mating network (Chapman 1990). Marginal communities would therefore benefit from long-range sea transport, as it lowers transport costs, places them in contact with more distant communities, and enables them to acquire a less peripheral position in a network.

Evidence for open-sea navigation in the Mediterranean after $7000 \mathrm{BC}$ is abundant (cf. Cherry 1990) and may demonstrate a wider pattern of exploiting the social opportunities offered by the sea.

Similar evidence can be found for the Adriatic. Frequent finds of large fish bones from Vela špilja on Korčula Island (such as tunny and swordfish) indicate deep-sea fishing. This implies proficient open sea navigation, aimed perhaps at the exploitation of rich sources of flint that are located on the opposite shore of the Adriatic. An igneous rock cobble associated with burial, which must have been brought from distant islets of Brusnik or Palagruža, is direct evidence of open sea navigation before the mid-seventh millennium BC (Forenbaher 2001).

I believe that the possibilities offered by sea navigation created an extensive social network covering a large part of the Mediterranean, which demonstrates the properties of "small-world" social networks.

It has long been recognized that the structure of social networks plays an important role in the dynamics of information propagation. Experiments in social network structures suggest that there are only about six intermediate acquaintances separating any two people on the planet. This is the so-called "small world" phenomena of social networks.

Any social network needs very weak requirements to exhibit a "small world" property: an underlying network structure of short links connecting neighbours and random, longer, short-cuts (Watts and Stogatz 1989).

In the case of the "Mesolithic Mediterranean small world" (Fig. 3), long-range shortcuts were established by sea travel connections in an underlying structure of mating networks along the coasts, where every community was connected to neighbouring communities (sensu Wobst 1974).

The small-world property of social networks in the Mediterranean and the increased individual mobility offered by the sea, provided channels for the fast dissemination of prestige items in the context of increased social tensions.

Low level of phylogeographic structure in goat mtDNA (see above) may also be result of mobility of stock across long-range exchange networks.

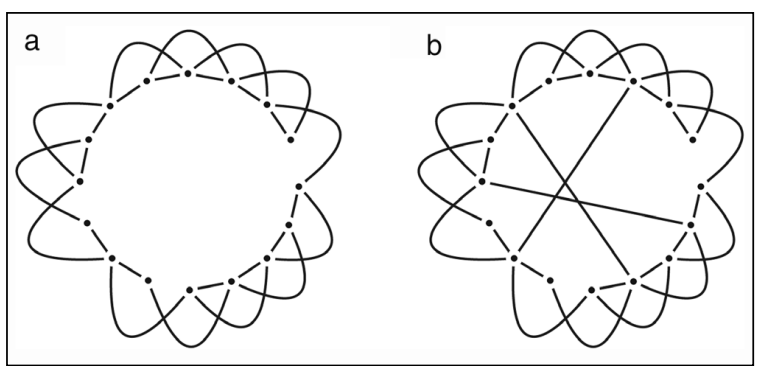

Fig. 3. The emergence of "small world" property in a social network. When some random short-cuts are added to the network (a), "small-world" social network emerge (b). 
Even in the most distant communities, sheep and goats - whether they were on the Mediterranean coast of the Levant, Anatolia, Greece or north Africa - were only a few marriages or boat trips away.

Although these animals were domesticated, communities, which acquired and incorporated them were not pastoralist (or Neolithic) societies. The mere adoption of domestic animals did not disrupt established ways of doing things. The transition to herding took place later, when adoption of an ideology of accumulation opened the door for larger herds, which were relied on for food.

\section{"NEOLITHIC SHEEP"!}

The short chronology of sheep and goat presence in the east Adriatic is far less problematic, although there are still open questions. In collections which define the short chronology of capriovid presence on the east Adriatic coast, two large patterns can be observed.

Pattern one can be observed in deeply stratified cave sites with a long history of occupation. Capriovid bones appear there in contexts which can be described as Mesolithic on the basis of continuity in the lithic industry, and as Neolithic on the basis of the presence of domesticated animals and - in most cases - small quantities of pottery.

In the Edera Cave (Stenašca) in the Trieste Karst, some uncharacteristic potsherds and a Castelnovian lithic toolkit were found (Biagi et al. 1993) in layer 3a, dated to ca. $5600 \mathrm{BC}$, together with a large number of capriovid bones (Boschin and Riedel 2000).

In Pupićina Cave in Istria, a full-blown pastoral economy can be observed in a layer dated to ca. $5600 \mathrm{BC}$ (Miracle 1997). No pottery was found. Unfortunately, late Mesolithic and early Neolithic layers that would document a transition to herding are absent from this site.

Similar patterns can be observed in deeply stratified caves in Herzegovina and Montenegro. Thus in Crvena Stjena layer III, Impreso pottery and a large collection of capriovid bones were found (Malez 1975), while the lithic industry displays continuity from Mesolithic layer IV.

Pattern two includes open-air sites located on coastal plains with arable land (Vižula, Tinj-Podlivade, Smiljčić, Pokrovnik...). They are usually flat and contain large quantities of Impresso pottery (Müller 1994) and complete package of domesticates.

Both patterns are spatially exclusive (Fig. 4). Pattern one can be found in peripheral, mountainous areas (Trieste Karst, Čičarija, Herzegovina, Montenegro) while pattern two sites are located in flat coastal plains with arable land (Ravni Kotari, Red Istria and Zagora region).

Both patterns display a different rate of adoption of domesticates and pottery. While the establishment of pattern two sites is roughly contemporary and falls within a very short time frame (contra Chapman and Müller 1990), pattern one sites seem to appear after the establishment of pattern two sites in same region.

The formation of patterns can be explained by two alternative scenarios. In the first scenario, early Neo-

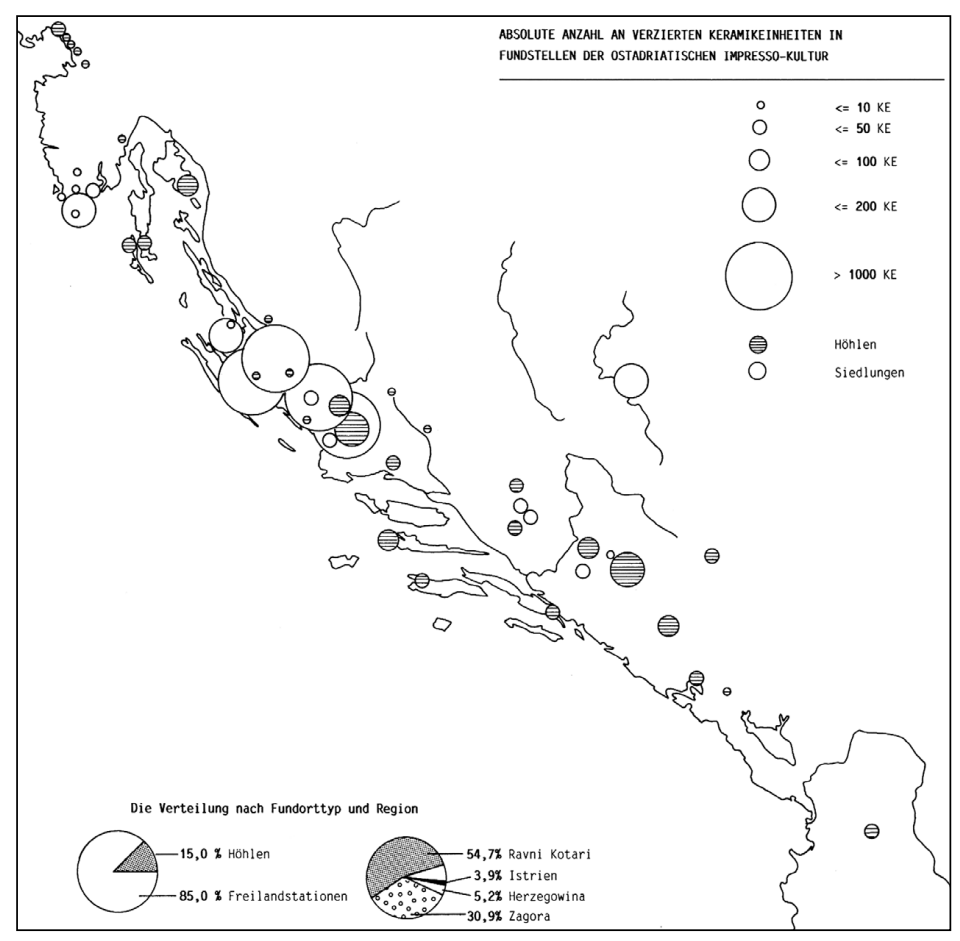

Fig. 4. The distribution and quantity of pottery in open air and cave sites in the east Adriatic (after Müller 1994.Abb. 1) 
lithic communities are established in niches suitable for mixed farming by maritime pioneer colonisation (cf. Zilhão 1998; 2001) around 6000 BC. A system of short-range mobility of sheep is soon devised, where herds are (seasonally) moved to caves located in more peripheral areas from lowland open-air settlements (see below). This may explain the sudden appearance of cave sites with Impresso pottery (Gospodska pećina...) in regions where pattern two sites are established.

Mesolithic communities then selectively adopt some aspects of the Neolithic package - mostly pottery and capriovids - and integrate into the wider regional division of labour as pastoralists. This process may be quite long, and may take several hundred years in some regions (Trieste Karst, Učka...).

In the second scenario, Mesolithic groups in coastal lowlands (with maritime contacts with Apulian Neolithic groups) adopt the complete package and begin to practice mixed farming. Groups in peripheral regions not suitable for farming begin to practice capriovid herding. Thus there gradually emerged two complementary economic systems which were integrated into a wider regional economic framework of divided labour (see below).

\section{FROM HUNTERS TO HERDERS}

Both scenarios sketched above assume the adoption of herding by Mesolithic groups. Yet the establishment of herding society was probably neither rapid nor smooth. There were many obstacles which slowed down the transition from hunting to herding societies. In fact, the process of the deep structural transformation of Mesolithic groups to full-blown herding societies was probably not over before the middle Neolithic.

An important source of information on the adoption of pastoralism, especially concerning its introduction to hunter-gatherers and their transformation, are the accounts of the American Southwest during Spanish colonisation in the 1700's (Bailey 1980).

Sheep were brought to the southwest of North America by the Spaniards in the late $16^{\text {th }}$ century. Within approximately 200 years pastoralism had changed the economy and social structure of the Navajo. When the Navajo were confronted with sheep in early 1700 s they were hunter-gatherers and horticulturalists. But then, within only a matter of decades, her- ding became a main subsistence strategy which profoundly changed their society, and they become a full-blown herding society. Bailey's (1980.77) conservative calculation of 7.5 years doubling rate for flocks in the $18^{\text {th }}$ century, gives the Navajo 8000 sheep by 1721,32000 sheep by 1735 and 64000 by 1742 , reaching a half-million by mid $19^{\text {th }}$ century a figure reported by a number of Anglo-American observes. The pressure on pastures was enormous, so herders were forced to seek for new grazing. Because of the growing flocks and limited grazing land patterns of vertical mobility - transhumance - were soon devised. One family often had up to three residences over an annual cycle. For this reason Bailey (1980.67-77) claims that it was not the horse that increased Navajo mobility, but sheep.

The main problems faced by early aspiring herders were probably social. There was probably strong tension between sets of conflicting values of sharing and accumulation. Lee (1979.412-413) observed tense relations between those families of the !Kung who had begun to farm and herd and their relatives who continued the foraging life. Yellen (in Hesse 1984.245) reports an interesting story of a !Kung San named Rakudu, who become a successful herder. However, he faced a serious problem when he was attempting to arrange a marriage for his eldest son. The trouble was that discussions with the father of most suitable bride had led nowhere because of objections raised on the narrow application of a usually ignored kinship rule by the potential inlaw. Legalistic objections were, of course, merely a cover for real objections. Rakudu and his sons had the reputation of being stingy, as they resisted suggestions to slaughter some animals for feasts. Thus the normal social obligations could not be met. Faced with the paradox of wealth and social alienation, Rakudu soon dropped herding.

Another set of problems early herders faced with was environmental. The main motivation for accumulation in pastoral societies is the immanence of catastrophe. Not only in the course of a seasonal cycle, but also in the longer term, flocks of small stocks are given to large and sudden fluctuations in size and change in age-sex structure. Compared with larger stock, they contain a higher risk factor, balanced by a capacity for rapid recovery due to their high fertility rates. If a herd is left unmanaged, its explosive growth potential leads quickly to the imposition of Malthusian population control. The tendency toward herd expansion is a fundamental feature of the pastoral mode of production (Cribb 1991.30). Thus 
the main limiting factor on herd expansion was lack of pastures.

As the sparse palinological data suggests, during the early Holocene the east Adriatic was covered with open woodland. Deciduous trees, mainly oak, predominated in these forests. Although evergreen species were present in the coastal regions, they remained of minor importance until about 6400-6000 BC, with the transition to a Mediterranean type of climate (Beug 1961; Brande 1989; summary in Chapman et al. 1996). There was a vegetational gradient from the Mediterranean type along the coast to a sub-Mediterranean in the uplands and a continental one further inland (Brande 1989). In the northern Adriatic (Istria and Karst) the woodland included thermophiluous trees as well as more cold-tolerant species; evergreen species were never as important as in southern Dalmatia (Beug 1977; Culiberg 1995, Andrič 2001).

The avaibillity of fodder (pastures) is the main limiting factor on herd growth. But on the other hand, sheep and goats change landscapes by browsing and grazing on young shoots, and therefore - in the long term - create new pastures. Since sheep and goat reproduce much faster than they open up new pastures, they are soon faced with Malthusian control. Thus in the long term we have a very complex ecological relationship between animals and pastures which is further complicated by catastrophic events which drastically reduce herds. The growth of herds thus follows a series of expansions and reductions, where every expansion pushes carrying capacity higher. This cycle frequency is somehow related to sheep reproduction rates, and is far too short to be detected archaeologically. However, the cumulative effect of grazing on the landscape can be observed in the palinological record.

There is sparse evidence for the impact of grazing on a regional scale. Changes in woodland composition, documented in the pollen core from Škocjanski zatok in north Istria (Culiberg 1995) can be explained by the impact of grazing. There is also strong evidence of extremely heavy localised impact at specific locales. At Podmol pri Kastelcu (Turk et al. 1993) "open vegetation" is documented in layers where capriovid bones predominate, and the low number of NAP may indicate that most of the grass was grazed before flowering.

Environmental data thus suggest that forest grazing was practised, and heavily grazed pastures existed around caves where animals were kept. This raises the question of mobility patterns and landscape use.

Hunter-gatherer movements across landscapes follow a complex spatial pattern covering the greater part of a well-defined territory or range and scheduling their movements with regard to consumption (cf. Binford 1980).

Pastoralists' utilisation of landscape is much simpler. They move according to the schedule of pastoral production, which is dependent upon the consumption patterns of flocks (Cribb 1993.20-22). They exploit the same basic resource - pasture - in different seasons. The main motivation behind pastoral movement is to maintain access to a single environmental niche by following its seasonal relocation (usually across a vertical gradient). Migration is motivated by a desire to optimize conditions for pastoral production and minimize risks to the herd. Shortrange transhumance systems have usually been suggested for the Neolithic (cf. Rowley-Conwy 1992).

Soil morphological evidence from the Trieste Karst suggests that caves were used as sheep pens, probably on a seasonal basis, as demonstrated by data from Pupićina Cave (Miracle 1997). The minimum number of individual capriovids in caves is usually very low (especially if we consider that it took at least a few hundred years for each layer to form), as is the quantity of pottery compared to open-air sites (Müller 1994). But thick deposits of animal dung (Boschian and Montagnari-Kokelj 2000) and environmental evidence of grazing around caves (Turk et al. 1993; see above) testify to an intensive seasonal presence of sheep. Caves, therefore, appear to be specialised sites, used mainly as (night?) shelters for animals. This may be compared to the practice of the New Mexico Navajo, who bedded their flocks close to their residences - hogans or rock shelters. They were allowed to graze nearby during the day, but in the evenings they were returned to the corrals (Bailey 1980.77).

In a lowland region, where we have evidence for open-air sites, perhaps a logistic (Binford 1980) pattern formed with caves "tethered" to central villages and visited by task specific groups with flocks on a seasonal schedule.

In marginal regions, where no open air-sites were found, caves may have been used as shelters for animals and shepherds in a system of residential mobility ("nomadism"), where families moved around the 


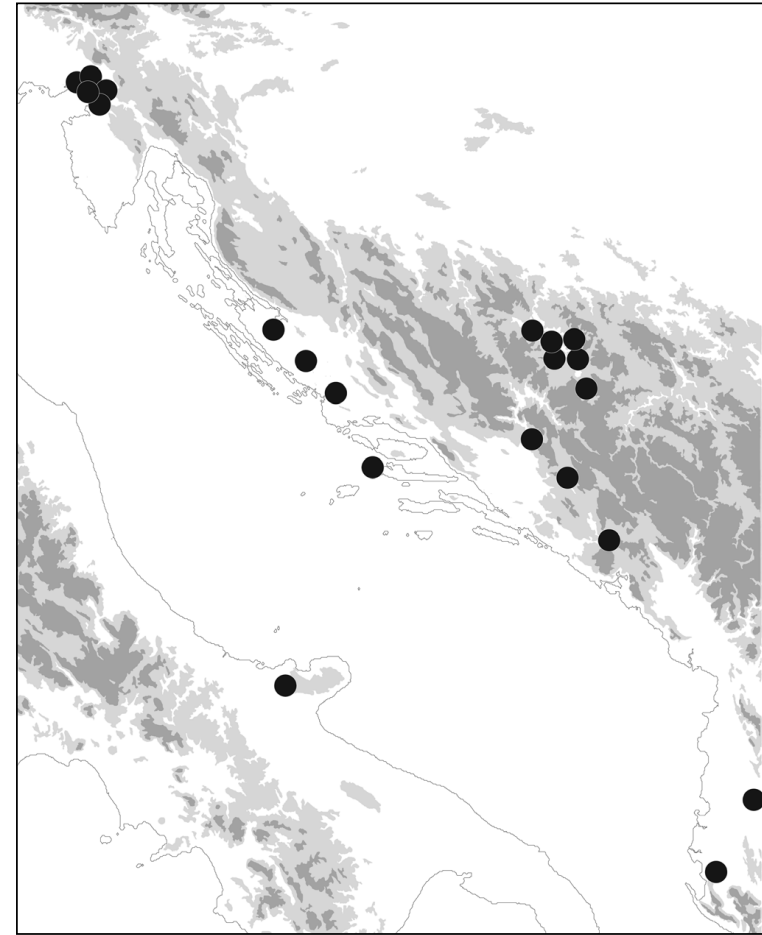

Fig. 5. Distribution of rhytons (after Perić 1996).

landscape with their flock in the course of yearly round. Both mobility startegies are documented among contemporary Navajo (Bloomberg 1983).

With a few exceptions, pastoralism is either combined with agriculture, or depends for its persistence on its integration with agriculture within a larger regional division of labour ( $c f$. Khazanov 1984). Thus herding emerged in regions where agriculture was established from the beginning; elsewhere, especially in more marginal regions, it was probably practiced alongside hunting or horticulture. Specialised pastoralist groups emerged probably not before the middle Neolithic, when we have widespread evidence of established pastoralism and when an interregional system of divided agro-pastoral labour and exchange emerged. The emergence of this wider economic system can be observed in the distribution of a special type of artefact the middle Neolithic rhyton ("vasi a quattro gambe"), which become widespread in the middle Neolithic, when pastoralsim become the main economic strategy. Although rhytons were interpreted as salt pots (Chapman 1988), its resemblance to a stylised (sheep?) udder or womb (Perić 1996) and its distribution in regions where sheep and goat were the main herding animals (Fig. 5) suggest that they were connected with a common set of values which were shared by east Adriatic herders. This interpretation may not contradict its possible role in the context of the salt trade, as salt became increasingly important for animal nutrition.

\section{CONCLUSION}

The transformation from hunter-gathering to herding societies which took place during the late Mesolithic and Neolithic on the east Adriatic coast was a deep structural transformation and not just an intensification of old strategies with new resources. Although it was basically a revolutionary change of values, the path to full-blown pastoralism was long and full of obstacles. Contradictions with old values, contrasts in the organisation of production, and problems in the scheduling of everyday activities attended the adoption of the herding way of life. It was much more than the mere incorporation of domestic animals into human society (Hesse 1984.245).

$\therefore$

\section{REFERENCES}

ANDRIČ M. 2001. Holocene vegetation dynamics and the formation of the Neolithic and present-day Slovenian landscape. In M. Budja (ed.), Documenta praehistorica 28: 133-176.

BAILEY L. R. 1980. If you take my sheep. The evolution and conflicts of Navajo Pastoralism: 16301868.

BEUG H.-J. 1961. Beiträge zür postglazialen Florenund Vegetationsgeschichte in Süddalmatien: der See "Malo Jezero" auf Mljet. Flora 150: 600-631.
1977. Vegetationsgeschichte Untersuchungen im Küstenbereich von Istrien (Jugoslawien). Flora 166: 357-381.

BASLER D 1983. Paleolitske kulture u jadranskoj regiji Jugoslavije. Glasnik Zemaljskoga muzeja u Sarajevu 38.

BENDER B. 1978. Gatherer-hunter to farmer: a social perspective. World Archaeology 10(2): 204-222.

BIAGI P., STARNINI E. and VOYTEK B. 1993. The late Mesolithic and early Neolithic settlement of northern 
Italy: recent consideration. Poročilo o raziskovanju paleolitika, neolitika in eneolitika v Sloveniji 21: 45-68.

BINDER D. 2000. Mesolithic and Neolithic interaction in southern France and northern Italy: new data and current hypotheses. In T. D. Price (ed.), Europe's first farmers: 117-143.

BINFORD L. R. 1980. Willow smoke and dogs' tails: hunter-gatherer settlement systems and archaeological site formation. American Antiquity 45: 4-20.

BLOOMBERG B. 1983. Mobility and sedentism: the Navajo of Black Mesa, Arizona. Center for Archaeological Investigation Research, Paper No. 23. Carbondale, Southern Illinois University at Carbondale.

BOSCHIN F. and RIEDL A. 2000. The late Mesolithic and Neolithic fauna of the Edera Cave (Aurisina, Trieste Karst): a preliminary report. Atti della Societá per la preistoria e protoistoria della regione Friuli-Venezia Giulia 8: 73-90.

BOSCHIAN G. and MONTAGNARI KOKELJ E. 2000. Prehistoric shepherds and caves in the Trieste Karst (Nort-eastern Italy). Geoarchaeology 15(4): 331371.

BRANDE A. 1989. Patterns of Holocene vegetation and landscape changes in south Dalmatia. Ecologia Mediterranea 15(1-2): 45-53.

BUDJA M. 1993. The Neolithisation of Europe. Slovenian aspect. Poročilo raziskovanju paleolitika, neolitika in eneolitika $v$ Sloveniji 21: 163-193.

1996. Neolithization of Europe. The Slovene Aspect. Contribution to the Discussion. Arheološki vestnik 47: 323-329.

CHAPMAN J. 1988. Ceramic production and social differentation: the Dalmatian Neolithic and the west Mediterranean. Journal of Mediterranean Archaeology 1(2): 3-25.

1990. Demographic trends in Neothermal SouthEast Europe. In C. Bonsall (ed.), The Mesolithic in Europe: papers presented at the third international symposium in Edinburgh 1985: 500-515.

CHAPMAN J. and MÜLER J. 1990. Early farmers in the Mediterranean basin: the Dalmatian evidence. Antiquity 64(242): 127-134.
CHAPMAN J., SHIEL R. and BATOVIĆ Š. 1996. The changing face of Dalmatia. Archaeological and ecological studies in a Mediterranean landscape. London, Leicester University Press.

CHERRY J. F. 1990. The first colonisation of the Mediterranean islands: a review of recent research. Journal of Mediterranean Archaeology 3: 145-221.

CREMONESI G., MELUZZI C., PITTI C. and WILKENS B. 1984. Grota Azzura: Scavi 1982 (Nota preliminare). Il Mesolithico sul Carso triestino, Società per la preistoria e protoistoria della regione Friuli-Venezia Giulia, Quaderno 5: 21-64.

CRIBB R. 1991. Nomads in archaeology. Cambridge, Cambridge University Press. (New studies in archaeology).

CULIBERG M. 1994 (1995). Desertification and reforestation of the Karst in Slovenia (Dezertifikacija in reforestacija slovenskega Krasa). Poročilo o raziskovanju paleolitika, neolitika in eneolitika v Sloveniji 22: 201-217.

CVIJIĆ J. 1966. Balkansko poluostrvo i južnoslovenske zemlje. Beograd, Zavod za izradu učbenika SFRJ.

FORENBAHER S. and VRANJICAN P. 1985. Vaganačka pećina. Opuscula archaeologica 10: 1-21.

FORENBAHER S. 2001. Vela špilja. A stratified praehistoric site. http://www.vela-spila.hr/eng/

GEDDES D. S. 1983. Neolithic transhumance in the Mediterranean Pyrenees. World archaeology 15: 51-66.

1985. Mesolithic domestic sheep in west Mediterranean Europe. Journal of Archaeological Science 12: 25-48.

HALSTEAD P. 1987. Traditional and ancient rural economy in Mediterranean Europe: plus ça change? Journal of Hellenistic Studies, CVII: 77-87.

HAYDEN B. 1990. Nimrods, piscators, pluckers, and planters: the emergence of food production.Journal of Anthropological Archaeology 9: 31-69.

1995. Pathways to power: principles for creating socioeconomic inequalities. In T. D. Price and G. M. Feinman (eds.), Foundations of social Inequality: 15-86. 
HESSE B. 1984. These are our goats: the origins of herding in west central Iran. In Clutton-Brock J. and Grigson C. (eds.), Animals and Archaeology: 3. Early Herders and their Flocks, vol. 202: 243-264.

HIENDLEDER S., LEWALSKI H., WASSMUTH R. and JANKE A. 1998. The Complete Mitochondrial DNA Sequence of the Domestic Sheep (Ovis aries) and Comparision with the Other Major Ovine Haplotype. Journal of Molecular Evolution, 47: 441-448.

HIENDLEDER S., MAINZ K., PLANTE Y., and LEVANSKI H. 1989a. Analyisis of mitochondrial DNA indicates that domestic sheep are derived from two different ancestral maternal sources. No evidence for contribution from Urial and Argali sheep. Journal of Heredity, 89: 113-120.

INGOLD T. 1980. Hunters, pastoralists and ranchers. Cambridge, Cambridge University Press.

1986. The appropriation of nature: Essays on human ecology and social relations. Manchester, Manchester University Press.

KHAZANOV A. M. 1984. Nomads and the outside world. Cambridge, Cambridge University Press.

LEE R. B. 1979. The !Kung San. Men, women and work in foraging society. Cambridge, Cambridge University Press.

LEWTHWAITE J. 1981. Plains tails from the hills: transhumance in Mediterranean Archaeology. In J. A. Sheridan and G. N. Bailey (eds.), Economic Archaeology. BAR int. series 96. Oxford, Archaeopress: 57-66.

LUIKART G., GIELLY L., EXCOFFIER L., VIGNE J., BOUVET J., and TABERLET P. 2001. Multiple maternal origins and weak phylogeographic structure in domestic goats. Proceedings of the National Academy of Sciences, 98(10): 5927-5932.

MACHUGH D. E. and BRADLEY D. G. 2001. Livestock genetic origins: Goats buck the trend. Proceedings of the National Academy of Sciences, 98(10): 5382-5384.

MALEZ M. 1975. Kvartarna fauna Crvene Stijene. Crvena Stjena - Zbornik radova. Nikšić.

MARKOVIĆ M. 1980 Stočarska kretanja na Dinarskim planinama. ZbNŽO, knjiga 45. Zagreb.
MIRACLE P. 1997. Early Holocene foragers in the karst of northern Istria. Porocilo raziskovanju paleolitika, neolitika in eneolitika v Sloveniji 24: 43- 61.

2001. Feast or famine? Epipaleolithic subsistence in the northern Adriatic Basin. In M. Budja (ed.), Documenta Praehistorica 28: 177-197.

MÜLLER J. 1994. Das ostadriatische Frühneolitikums. Die Impresso-Kultur und die Neolithisierung des Adriaraumes. Prähistorische Archäologie Südosteuropas 9.

OLARIA C. 1988. Cova Fosca: un asentamiento meso-neolithico de cazadores y pastores en la serranía del Alto Maestrazgo. Monografies de Prehistoria i Arquelogia Castellonenques 3. Castelon: Disputación de Castelón.

PERIĆ S. 1996. Kult-Rythone der neolitischen Vierhzüchter der Balkanhalbinsel. Starinar 47: 21-66.

POHAR V. 1986. Kostni ostanki iz mezolitskega najdišča Pod Črmukljo pri Šembijah (Ilirska Bistrica). Poročilo o raziskovanju paleolitika, neolitika in eneolitika v Sloveniji 14: 11-20.

RIEDEL A. 1975. La fauna epipaleolitica della grotta Benussi (Trieste). Atti e memorie della commissione grotte "E. Boegan" 15: 123-144.

ROWLEY-CONWY P. B. 1992. Arene Candide: a small part of a larger pastoral system. In R. Maggi, R. Nisbet and G. Barker (eds.), Archeologia della pastorizia nell'Europa meridionale. Rivista di studi Liguri A. 61, 1-4: 95-116.

RYDER M. L. 1984. Sheep and man. London. Duckworth.

SAHLINS M. 1972. Stone age economics. Chichago, Aldine.

STERUD E. 1978. Prehistoric populations of the Dinaric Alps: an investigation of Interregional interaction. In C. L. Redman, M. J. Berman, E. V. Curtin, W. T. Versaggi and J. C. Wanser (eds.), Social archaeology: beyond subistence and dating: 381-408.

ŠAŠEL J. 1979. Aditus ad aquam. Traditiones 5-6: 353-361.

TURK I., MODRIJAN Z., PRUS T., CULIBERG M., ŠERCELJ A., PERKO V., DIRJEC J. and PAVLIN P. 1993. 
Podmol pri Kastelcu - novo večplastno arheološko najdišče na Krasu, Slovenija. Arheološki vestnik 44: 45-96.

ZILHÃO J. 1993. The spread of agro-pastoral economies across Mediterranean Europe: a view from the far west. Journal of Mediterranean Archaeology 6: 5-63.

1998. Maritime pioneer colonisation in the early Neolithic of the west Mediterranean. Poročilo o raziskovanju paleolitika, neolitike in eneolitika v Sloveniji 24: 19-24.

2001. Radiocarbon evidence for maritime pioneer colonization at the orogins of farming in west Mediterranean Europe. Proceedings of the National Academy of Sciences, 98(24): 14180-14185.

VELUŠČEK A. 1995. Proces neolitizacije kot prehod h kmetovanju, prepoznan v mezolitskih kontekstih kraške Dinarske Slovenije? Arheološki vestnik 46: 327-337.
VRIŠČAK T. 1989. Kuda idu "horvatski nomadi"? Studia Ethnologica 1: 79-98.

WARREN G. 1997. Seascapes: Navigating the coastal Mesolithic of Western Scotland. Assemblage 2. http:// http://www.shef.ac.uk/assem/2/2war1.html

WATTS D. J and STROGATZ S. H. 1998. Collective dynamics of 'small world' networks. Nature 393(4): $440-442$.

WILKENS B. 1992. Il ruolo della pastorizia nelle economie preistoriche dell'Italia centro-meridionale. In R. Maggi, R. Nisbet and G. Barker (eds.), Archeologia della pastorizia nell'Europa meridionale. Rivista di studi Liguri A. 61, 1-4: 81-94.

WOBST M. 1974. Boundary conditions for Palaeolithic social systems: a simulation approach. American Antiquity 39: 147-178. 